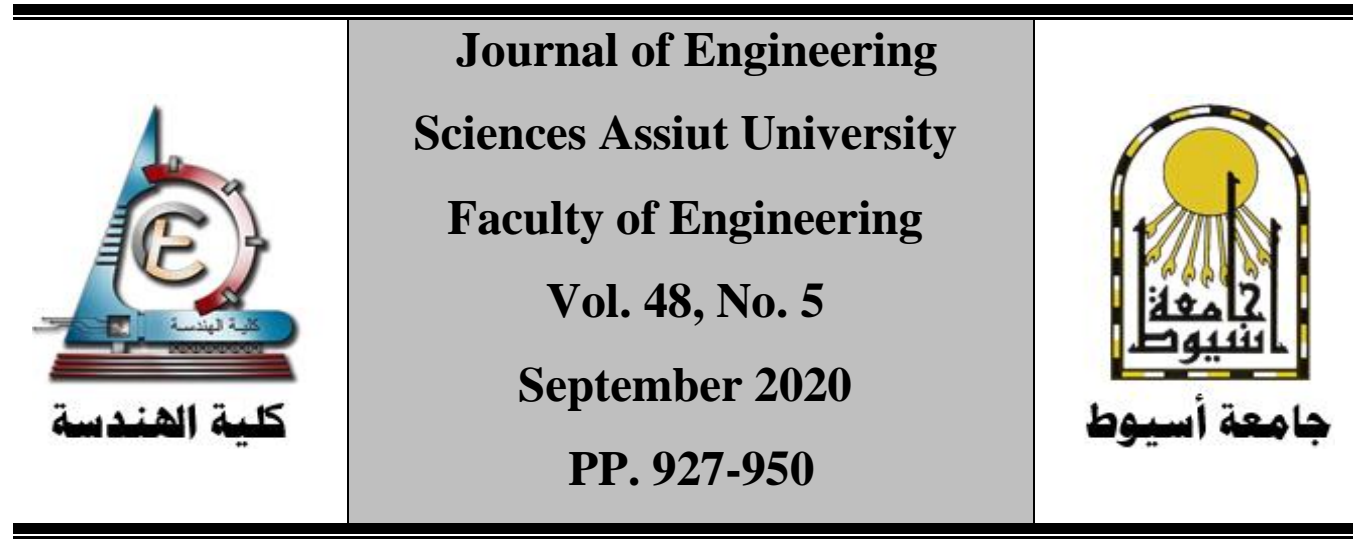

\title{
INFLUENCE OF THE RESERVOIR SEDIMENTATION ON THE DAM OPERATION - A STUDY OF ASWAN HIGH DAM IN EGYPT
}

\author{
Amir M. Mobasher ${ }^{1}$ \\ ${ }^{1}$ Assoc. Prof., Department of Civil Engineering, Faculty of Engineering, Al-Azhar \\ University, Egypt. E-mail: amir_mobasher@cic-cairo.com
}

Received 10 April 2020; Revised 19 May 2020; Accepted 31 May 2020

\begin{abstract}
Reservoirs are an important source of water supply, provide hydropower, reduce the deficiency influences, and provide flood protection. Due to the dam structure and reservoir founding, the releases from the dam has become more restrained and the hanging sediment concentricity summits have been decreased considerably and accumulated upstream the dam. Sediment siltation has increasingly reduced the efficiency of reservoir functionality throughout the years by declining the storage capability. Determining the reservoir sedimentation influence on the dam operation is important to holding current operation and preparing for future polices. The existing paper deals with the review and assessment of the reservoir sedimentation effect on operation of Aswan High Dam (AHD) in Egypt. A new simulation model was developed and calibrated for Aswan High Dam Reservoir (AHDR) to evaluate the reservoir sedimentation effects on the factors affecting the operation of the dam. These factors are Toshka spillway outflows, upstream water levels of AHD, dam safety, withdraw from the reservoir, the losses due to the evaporation and the hydropower generation from AHD. The results of the study displayed that the factors affecting the operation of AHD were affected due to presence of these deposits in AHDR. Therefore, the reservoir sedimentation effect should be considered to implement or develop of simulation models for AHDR.
\end{abstract}

KEYWORDS: Reservoir, Sedimentation, Dam Operation, Aswan High Dam, Nile River. 


\section{Sedimentation Problems in Reservoirs}

Although the advantages realized, dam reservoirs are not without their disadvantages. The reduction in the capability of the reservoir storage and its useful life due to the sedimentation is considered critical issue. This reduction declines the mitigation of the overflow and rises the outflows. In addition to these, the hydraulic and structural safety of reservoirs can be also influenced by the sedimentation.

The reservoir sedimentation problem has raised all over the world from year to year. A study was done on the world's 145 large rivers with harmony long period sediment records and the outcomes evidence that about $50 \%$ of the rivers have statistically a considerably falling flow direction because of sedimentation [1]. Sumi \& Hirose (2009) stated that the overall reservoir whole storage capacity is about $6000 \mathrm{~km}^{3}$ and yearly reservoir sedimentation estimates are about $31 \mathrm{~km}^{3}$ $(0.52 \%)$. This suggests that at this sedimentation estimate, the overall reservoir storage capacity will be decreased to $50 \%$ by year 2100 [2].

In Brazil. Carvalho (1998) reported that several reservoirs have been endangered to growing deficits of their storage capacities. in accordance with that author it is calculated that the Brazilian reservoirs may be missing $0.5 \%$ of their volume annually [3]. In India. Kande (2017) examined capacity of the Khodiyar Reservoir in Gujarat state of India. He found that the designed storage capacity of reservoir was 40.39 million $\mathrm{m}^{3}$ in the year of 1967 , with the sediment deposition of 14.73 million $\mathrm{m}^{3}$ it decreases to 25.80 million $\mathrm{m}^{3}$ in 41 years. This reduction gets out to be $36.12 \%$, displays the larger value of siltation [4]. Shiyang Reservoir in China had its capacity decreased after $43 \%$ of woodland zones inside its catchment were became into agricultural land. In Ghana a same investigation to evaluate the influence of land utilize amendments on the Burekese catchment was carried out and the findings stated a loss in reservoir storage capacity of $45 \%$ due to siltation during a time of six years [5].

Many dams exist along the Nile River for various purposes. The sedimentation, within their reservoirs, reduces their capacity and their practical life span. The Sennar Dam was constructed in year 1925 on the Blue Nile (Sudan) and it was original capacity was $\left(930\right.$ million $\mathrm{m}^{3}$ ) and due to the sediment deposition within (61 years) the dam lost $71 \%$ of its original capacity $\left(660\right.$ million $\left.\mathrm{m}^{3}\right)$. Also, the Roseires Dam was constructed on the Blue Nile (Sudan) in year 1964. It was original capacity $\left(3.3 \mathrm{~km}^{3}\right)$. The design rate of sedimentation was $\left(15\right.$ million $\mathrm{m}^{3}$ per year) but what was happening in the reservoir since then, where the average of sedimentation is (43 million $\mathrm{m}^{3}$ per year). In 28 years (1964- 1992), the capacity reduced about $36 \%\left(1.2\right.$ million $\left.\mathrm{m}^{3}\right)$ [6]. 


\section{Sedimentation problem in AHDR}

AHDR case study is very important in its own right. It exemplifies the lengthy period reservoir for the flowing water to Egypt from the Nile river. Therefore, unique, and nationwide importance should be given to AHDR operation and enhancement. Under natural flow conditions, the maximum intensities of the hanging sediments are transported to AHDR by the Nile as it crossed the northeastern desert of Africa and deposited in its lesser path as rich alluvial soil. The main sources of suspended matter are the Atbara and Blue Nile Rivers. Ninetyfive percent of sediments originate from the Ethiopian Plateau through the Atbara and Blue Nile Rivers and less than 5\% from Equatorial Lakes through the White Nile and its branches (see Fig. 1) [7,8].

Before AHD operation, all major hydraulic structures including the Old Aswan Dam were designed and built in such a way as to permit the suspended sediments, during flood flow to be carried through the reservoirs and then moves along the river path to the sea. As AHD was designed as an over year storage reservoir, most of the rivers suspended sediments are accumulated in the upstream reservoir [9]. Prior to AHD operation, in 1960, 9-10 million tons of suspended sediment were deposited annually on the Nile flood plains, while about 124 million tons which represents approximately $93 \%$ of the mean annual hanging load was carried out to the sea. From the date of the whole operation of AHD in 1971, the Nile outflow, downstream AHD, has been largely amended and in excesses of $98 \%$ of the total hanging load was retained in AHDR and the whole quantity of sediment transported downstream the reservoir dropped to only 2.5 million tons/year [10].

It was estimated that more than 134 million tons per year is deposit in AHDR and has altered reservoir volume. These accumulated sediments are influencing the storage volume of AHDR [11]. The sediment siltation is condensed at the inlet of AHDR, it is observed that from year 1964 to 2000 the thickness of the deposition layer may be more than 60 meters in the past 36 years at the inlet of AHDR and the estimation sediment deposition was (5.2 milliard tons) [12, 13]. Hassan 2008 calculated the amount of sediments and the volume of storage of AHDR by two approaches, the traditional approach: cross section approach and the advanced approach. The results showed that sum of the sedimentation volume in AHDR at year 2006 equal to $6018 \mathrm{~km}^{3}$ dividing into $2673 \mathrm{~km}^{3}$ under water level 147.00 meter above mean sea level (m amsl) and $3345 \mathrm{~km}^{3}$ between water level $147.00 \mathrm{~m}$ amsl and water level $175.00 \mathrm{~m}$ amsl and no sedimentation above water level 175.00 $\mathrm{m}$ amsl [14].

Figure 2 displays the sediment transport along several years from year 1964 till year 2012 for AHDR. 


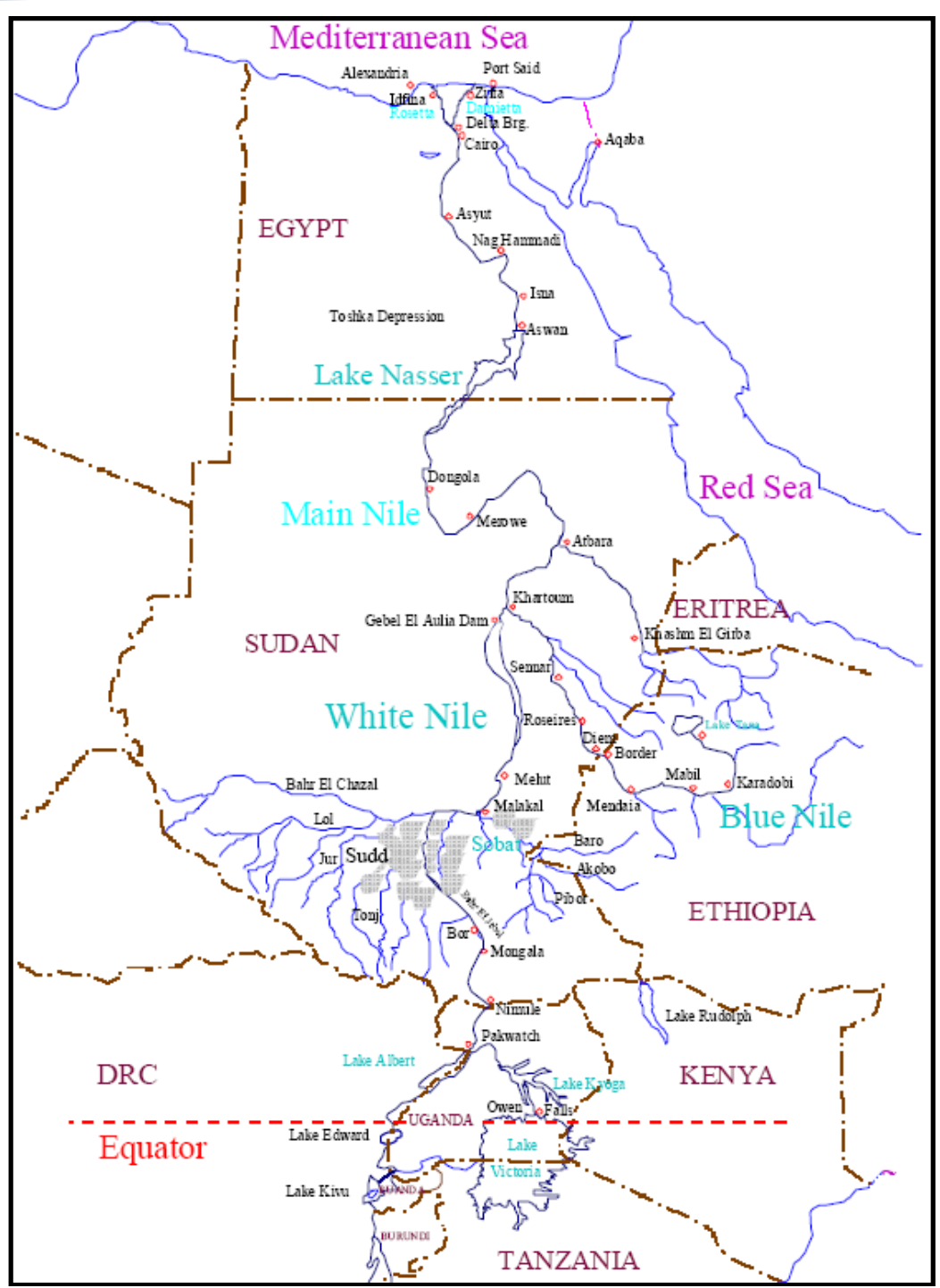

Fig. 1. Map of the River Nile Basin [7].

\section{Methodology}

This paper focuses on the sedimentation effect in AHDR on AHD operation. At the beginning, an inventory was made of the recent studies in the field of estimating the size of sediments in AHDR and their effect on the reservoir storage capability. Then the following steps should be followed:

- For begin a simulation certain input data needs to be required. In this case, the necessary information involves of the following elements: features of AHDR, 
the sedimentation impact on the storage capability of AHDR, effect of reduction of storage capability on operation of AHDR and potential inflow scenarios.

- A new mathematical model was prepared to evaluate the impact of these deposits on the reservoir operation and estimating the releases from AHD and the losses due to the evaporation and the outflows to Toshka spillway. Different Nile inflows scenarios to AHDR were considered during this analysis.

- The change in the various factors affecting AHD operation was highlighted.

- Finally, assessments and conclusions were presented as well.

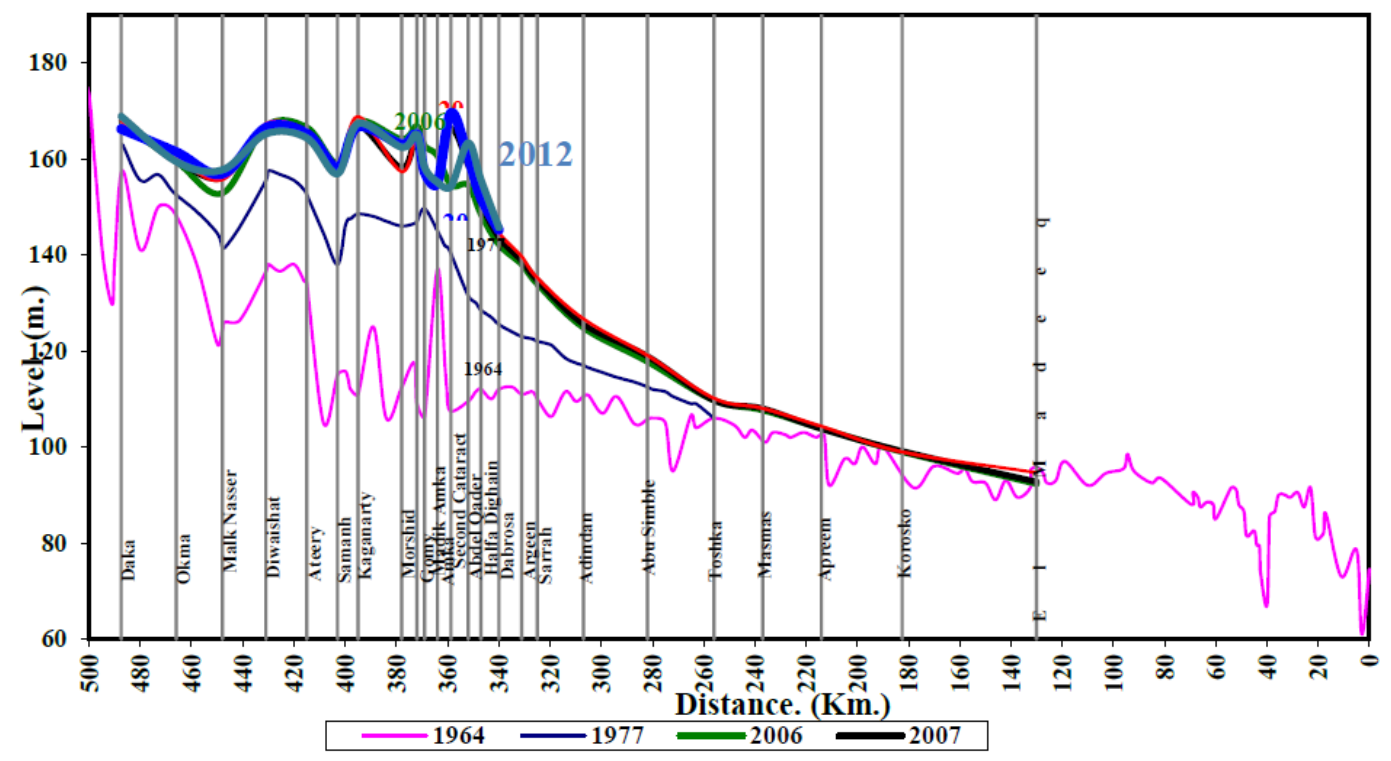

Fig. 2. A longitudinal section in AHDR [15].

\section{Features of AHDR}

AHDR (knowing Lake Nasser) is a reservoir shaped by reason of the built of AHD. The reservoir is $500 \mathrm{~km}$ long with more than $350 \mathrm{~km}$ in Egypt and the remainder in Sudan (see Fig. 3). The reservoir storage volume has an amount of $162 \mathrm{~km}^{3}$ and an area of surface about $6500 \mathrm{~km}^{2}$ for the highest level of water $182 \mathrm{~m}$ upstream AHD. The capability of storage is segregated to three portions as follows: dead or inactive storage volume of $31.6 \mathrm{~km}^{3}$ up to $147 \mathrm{~m}$ amsl, live or working storage capacity between the levels 147 and $175 \mathrm{~m}$ amsl, mounting to $90.4 \mathrm{~km}^{3}$, which guarantees the annual requirements of water, and flood control capacity of $40 \mathrm{~km}^{3}$ between levels 175 and $182 \mathrm{~m}$ amsl [17]. 


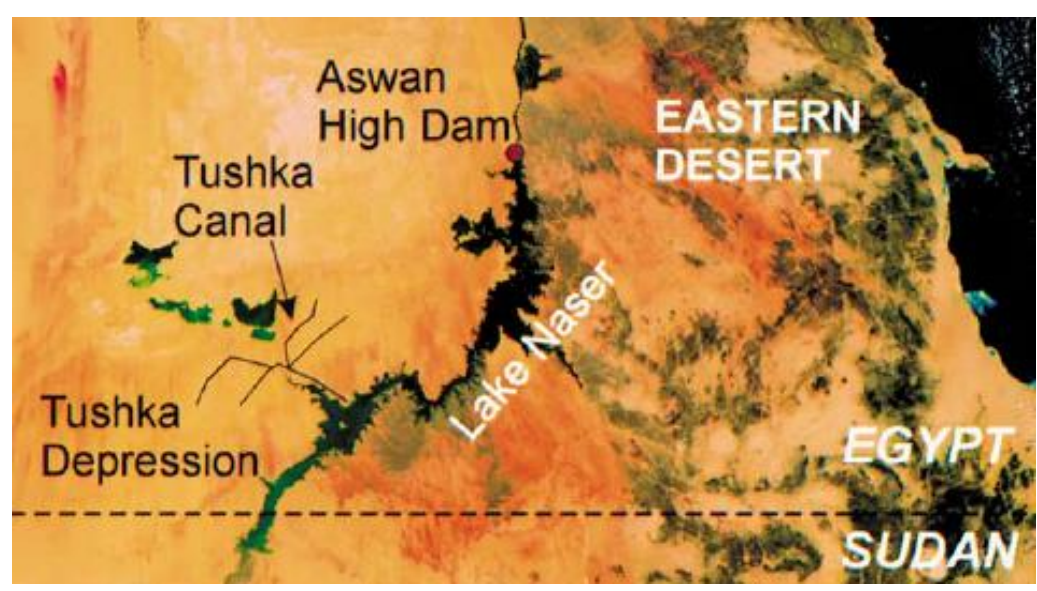

Fig. 3. Location of AHDR (knowing Lake Nasser) [16].

\section{The sedimentation influence on storage capability of AHDR}

El-shazli and Hoermann used a digital elevation model (DEM), in addition to satellite images to identify the variations in the storage capability and storage area of AHDR across the last 50 years. Study conclusions designate that the water volume of AHDR assessed by the DEM at an elevation of $182 \mathrm{~m}$ amsl is about $142.0 \mathrm{~km}^{3}$. This amount is divided into three zones; the inactive or dead storage zone has a top elevation of $147 \mathrm{~m}$ amsl with total volume of about $25 \mathrm{~km}^{3}$. The active or live storage zone, which amounts to $78.0 \mathrm{~km}^{3}$, lies between elevation 147 $\mathrm{m}$ amsl and $175 \mathrm{~m}$ amsl. An additional storage volume of $39 \mathrm{~km}^{3}$ is available for high flood waters, it is between elevation of $175 \mathrm{~m}$ amsl and $182 \mathrm{~m}$ amsl. The main cause for the loss of about $12 \%$ of the storage capability is sediment deposition. This storage capability loss occurred mostly in the working (live) and the inactive (dead) storage zones and slightly in the flood control zone, as noticeably obvious in Table 1. Also, the compare of the established area curve by DEM, and the design curve of AHDR assessed by "Ministry of Water Resources and Irrigation" (MWRI) shows that the design curve is greater than the new curve, and the variances among them increase as the level of water rises, in particular between water levels of 140 and $168 \mathrm{~m}$ amsl The average reduction in the area of surface among water levels 140 and $168 \mathrm{~m}$ amsl is about $15 \%$. Above level of $168 \mathrm{~m}$ amsl the variances among the two curves decrease with a raise in the level of water. The area of surface for AHDR valued by DEM at level of $182 \mathrm{~m}$ amsl is $6350 \mathrm{~km}^{2}$. This value is different from the value estimated by MWRI, which is about $6540 \mathrm{~km}^{2}$ and was estimated via 1:25000 topographic maps [18].

The results of El-shazli and Hoermann's study are compatible with many recent studies. For example, Shafik (2016) [19] find that the water volume of AHDR 
assessed by Surfer and ArcGIS methods at an elevation of $182 \mathrm{~m}$ amsl is about $141.41 \mathrm{~km}^{3}$ (the loss of about $12 \%$ of the storage capability). The area of surface for AHDR valued by Surfer and ArcGIS methods at level of $182 \mathrm{~m}$ amsl is 6455.78 $\mathrm{km}^{2}$. Also, the area-water level-capacity curve for AHDR inferred by Shafik' study was agreeable approximately with the study of El-Shazli and Hoermann.

Table 1: The whole storage capability of AHDR [18].

\begin{tabular}{|c|c|c|c|c|c|}
\hline $\begin{array}{c}\text { Storage } \\
\text { zone }\end{array}$ & $\begin{array}{c}\text { Water } \\
\text { level } \mathbf{( m} \\
\text { amsl) }\end{array}$ & $\begin{array}{c}\text { Storage } \\
\text { capacity in } \\
\mathbf{1 9 6 4} \\
\left.\mathbf{( k m}^{3}\right)\end{array}$ & $\begin{array}{c}\text { Storage } \\
\text { capacity in } \\
\mathbf{2 0 1 3} \\
\left.\mathbf{( k m}^{\mathbf{3}}\right)\end{array}$ & $\begin{array}{c}\text { Reduction } \\
\text { of storage } \\
\text { capability } \\
\left(\mathbf{k m}^{\mathbf{3}}\right)\end{array}$ & $\begin{array}{c}\text { Reduction of } \\
\text { storage } \\
\text { capability } \\
(\mathbf{\%})\end{array}$ \\
\hline $\begin{array}{c}\text { Dead } \\
\text { storage } \\
\text { zone }\end{array}$ & $<\mathbf{1 4 7}$ & 31.60 & 25.00 & 6.60 & 20 \\
\hline $\begin{array}{c}\text { Live } \\
\text { storage } \\
\text { zone }\end{array}$ & $\mathbf{1 4 7 - 1 7 5}$ & 90.40 & 78.00 & 12.40 & 14 \\
\hline $\begin{array}{c}\text { Flood } \\
\text { Control } \\
\text { zone }\end{array}$ & $\mathbf{1 7 5 - 1 8 2}$ & 40.00 & 39.00 & 1.00 & 2.50 \\
\hline Sum & & 162 & 142 & 20 & 12 \\
\hline
\end{tabular}

\section{Effect of reduction in storage capability on AHD operation}

According to study findings of El-shazli and Hoermann (2016) [18], it is evident that AHDR storage capability is influenced by the sediments amount inside it. Therefore, the area-water level-capacity curve for AHDR should be modified when examining the sedimentation impact on AHD operation. Figure 4 shows relationships of the designed storage capability and storage area against level of water for AHDR as provided by MWRI in 1964 and the modified according to DEM estimation in 2013. From the curves in Figure 4, It can be concluded that the equations governing the relation between the water level and the surface area of AHDR is [18]:

$$
\begin{array}{ll}
\text { In } 1964 & S a=E l^{6.287} * 4 \times 10^{-11} \\
\text { In } 2013 & S a=E l^{6.9895} * 1 \times 10^{-12}
\end{array}
$$

The equation governing the relation between the water level and the storage capacity of lake Nasser is [18]:

$$
\text { In } 1964 V=E l^{7.7640} * 4.6847 \times 10^{-16}
$$


In $2013 \quad V=E l^{8.5697} * 6.3634 \times 10^{-18}$

Where:

$\boldsymbol{V} \quad$ : The reservoir storage in $\mathrm{km}^{3}$.

$\boldsymbol{E l}$ : The reservoir elevations in meters.

$\mathrm{Sa}$ : The reservoir surface area $\mathrm{Km}^{2}$.

The data of these curves and the deduced equations will be used in the modeling process in the current paper for the purpose of compare AHDR operation in both cases (with \& without) taking the sedimentation in the consideration.

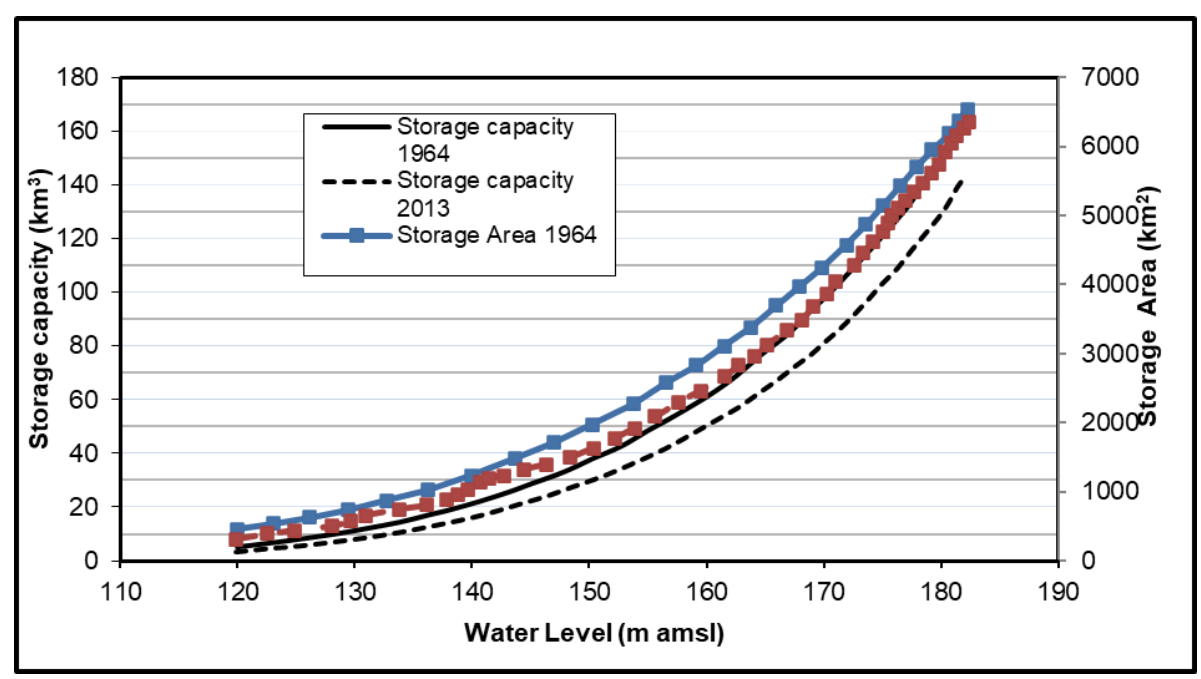

Fig. 4. (Water level - Capacity - Area) curve [18].

\section{Scenarios of inflow at AHDR}

To examine the sedimentation influence on AHD operation, this should be tested in the presence of various scenarios of Nile water flows to AHDR. For this reason, statistical examination should be done for various inflow events to find the important events of sequential inflows. The available data consist of 48 years from monthly River Nile Inflows at Dongola in Sudan (representing the inflows to AHDR) [r·] (from 1964 to 2011) to evaluate and analyze the flood as displayed in Figure $5\left[r^{\prime}\right.$ ]. The frequencies of River Nile inflow to AHDR for the interval 19682011 are displayed in Figure 6. These data have a minimum of $40.89 \mathrm{~km}^{3} /$ year, mean of $69.73 \mathrm{~km}^{3} /$ year (distribution of this amount on the months is illustrated in Table 2). A median of $94.16 \mathrm{~km}^{3} /$ year and a maximum of $107.05 \mathrm{~km}^{3} / y e a r$ with the standard deviation of $15.65 \mathrm{~km}^{3} /$ year. 


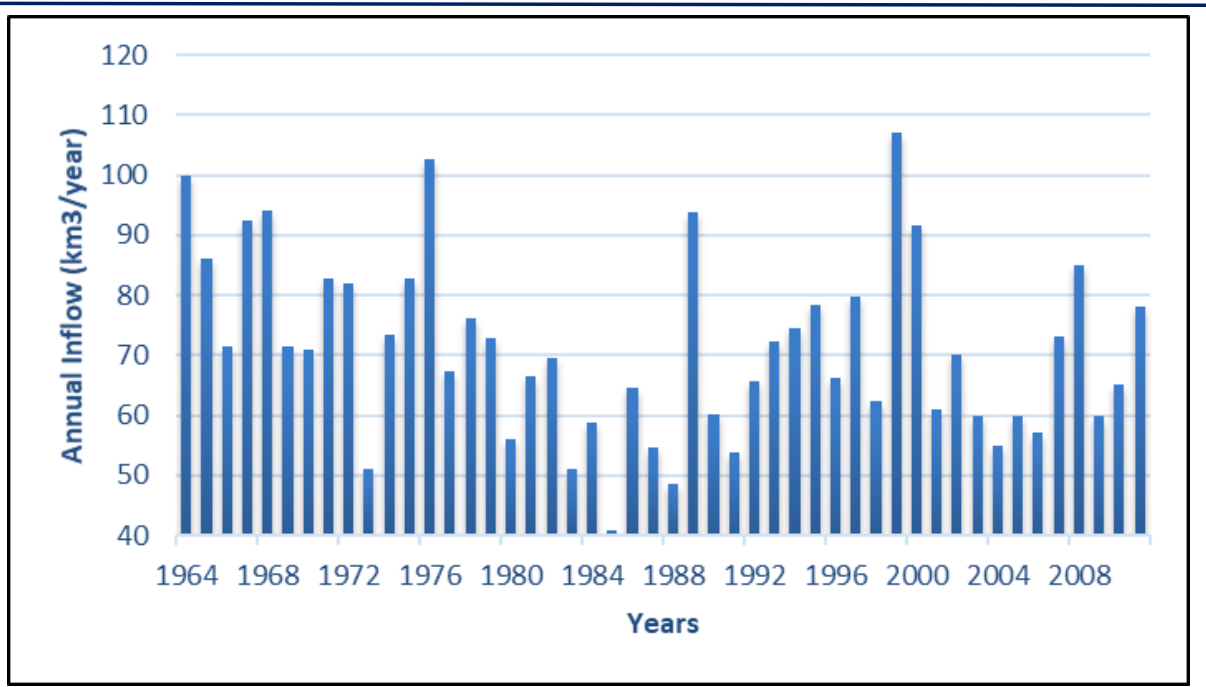

Fig. 5. Annual Inflows at AHDR from (1964-2011) [21].

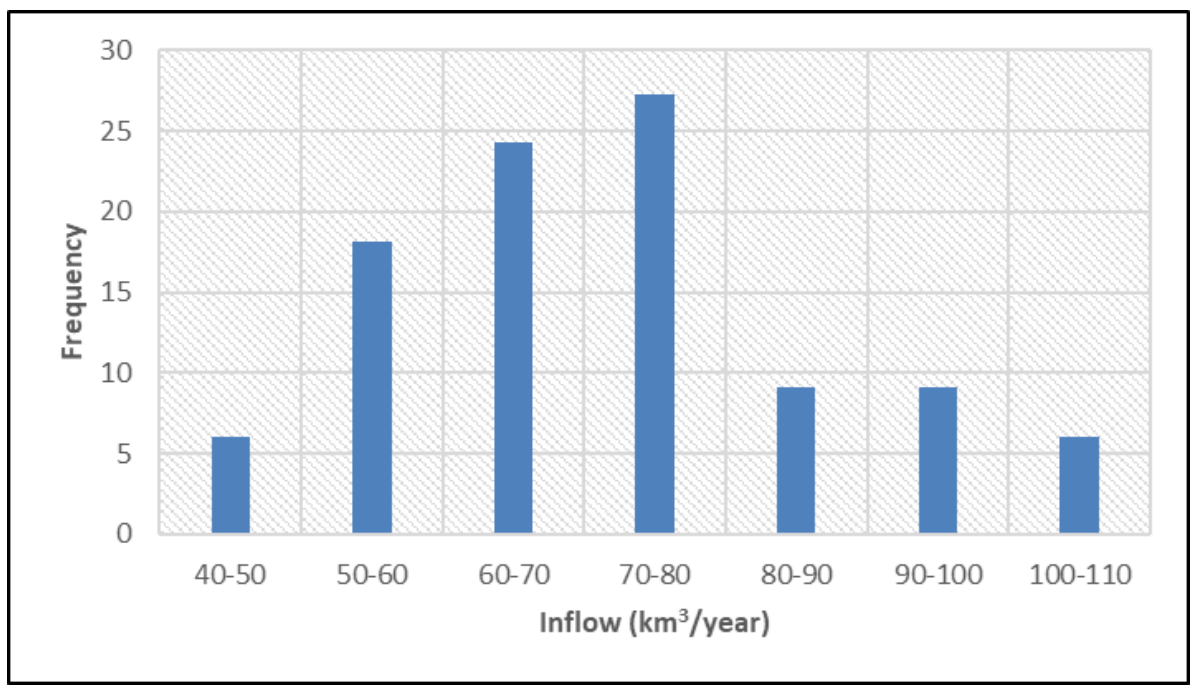

Fig. 6. Frequencies of annual inflows at AHDR from (1964-2011).

To evaluate the sedimentation impact on AHD operation, 5 Nile inflows scenarios to AHDR were selected and presented in Table 3. The selected scenarios will be used as a multiplier to the historical natural series (1964-2011) to the model for simulation potential inflows to AHDR. 
Table2: Distribution of mean annual inflow at Dongola expressed in $\mathrm{km}^{3} / \mathrm{month}$ during period (1964-2011) [21].

\begin{tabular}{|l|c|c|c|c|c|c|c|c|c|c|c|}
\hline Jan & Feb & Mar & Apr & May & Jun & Jul & Aug & Sep & Oct & Nov & Dec. \\
\hline 3.14 & 2.42 & 2.06 & 2.87 & 2.98 & 2.53 & 5.02 & 16.54 & 15.40 & 8.81 & 4.62 & 3.35 \\
\hline
\end{tabular}

Table 3: Studied inflow scenarios.

\begin{tabular}{|c|c|c|}
\hline Scenario & \% of inflow & $\begin{array}{c}\text { Corresponding average inflow to AHDR } \\
(\mathbf{k m} / \mathbf{y e a r})\end{array}$ \\
\hline 1 & Baseline & 69.73 \\
\hline 2 & $10 \%$ Increase & 76.70 \\
\hline 3 & $20 \%$ Increase & 83.68 \\
\hline 4 & $10 \%$ Decrease & 62.76 \\
\hline 5 & $20 \%$ Decrease & 55.78 \\
\hline
\end{tabular}

\section{Simulation Model}

\subsection{Model idea and influential formulas}

To determine the sedimentation impact on AHD operation, AHDR is modeled and its operation is simulated and coded using FORTRAN language. The developed model is supported on piecewise linearization conception method [22]. The piecewise linearized analytic approach offers the opportunity to determine multiple processes being non-linear functions of storage content for a chosen time arbitrary interval without excessive numerical iterations. The approach was extended to consider several inflows $Q_{\text {in,i }}$ and outflows $Q_{\text {out,j }}$ which can either be independent of storage or can be a function of the storage content as displayed in Figure 7. In

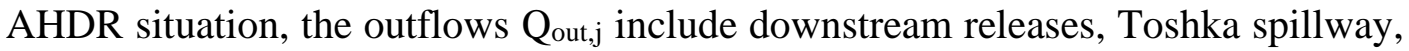
Toshka project (South Valley), evaporation and seepage losses.

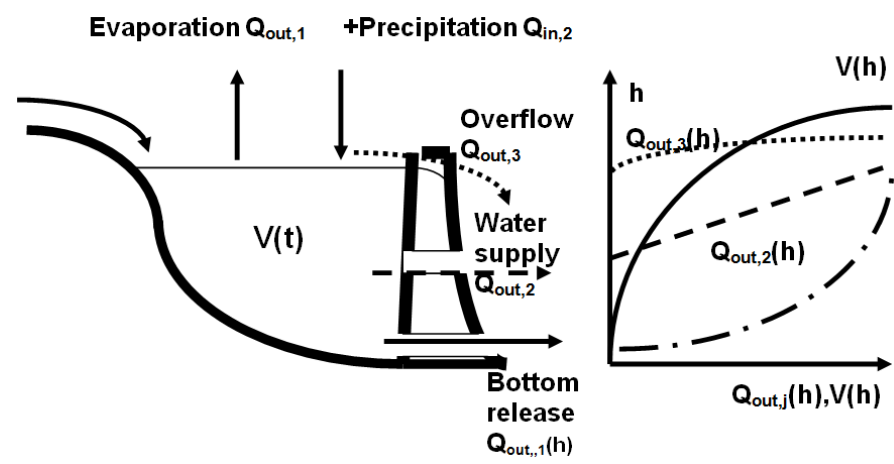

Fig. 7. A multiple input-output reservoir element [22]. 
It should be emphasised that both constant flows and volume dependent flows can be positive or negative. This is important as it provides the opportunity to also define inflows as being dependent on the state variable. This modifies the equation of continuity to Eq. 5

$$
\frac{d V(t)}{d t}=\sum_{i=1}^{n_{i n}} Q_{i n, i}+\sum_{j=1}^{n_{o u t}} Q_{o u t, j}
$$

According to Figure 8, the process Qut $_{\text {was defined as piecewise linear functions }}$ of storage. It is obvious that under the hypothesis of equal breakpoints i of the state variable $\mathrm{V}$ for the piecewise linearization of all dependent processes, the solution is identical to the one already presented. The dependent and independent $\mathrm{j}$ process terms are then summarised according Eq. 6:

$$
\sum_{j=1}^{n_{\text {out }}} Q_{\text {out }, j}=\sum_{j=1}^{n_{P}}\left(Q_{\text {out }, j, k-1}-k_{j, k} \cdot V_{j, k-1}\right)+\sum_{j=1}^{n_{\text {out }}} k_{j, k} \cdot V(t)
$$

Inserting Eq. 2 into the equation of continuity results in Eq. 7:

$$
\frac{d V}{d t}=\underbrace{\sum_{i=1}^{n_{\text {in }}} Q_{i n, i}+\sum_{j=1}^{n_{\text {out }}}\left(Q_{\text {out }, j, k-1}-k_{j, k} \cdot V_{j, k-1}\right)}_{\mathrm{C} 1}+\underbrace{\sum_{j=1}^{n_{\text {out }}} k_{j, k} \cdot V(t)}_{\mathrm{C} 3}
$$

By setting $\mathrm{C} 3=-\mathrm{C} 2$ and subsequent substitution we arrive at Eq. 8:

$$
\frac{d V}{d t}=C 1-C 2 \cdot V(t)
$$

With known solution in Eq. 9 for the volume and Eq. 10 for the required time to boundary:

$$
\begin{gathered}
V(t)=\frac{C 1}{C 2} \cdot\left[1-\mathrm{e}^{-C 2 \cdot\left(t-t_{0}\right)}\right]+V_{0} \cdot \mathrm{e}^{-C 2 \cdot\left(t-t_{0}\right)} \\
t_{\lim i t}=-\frac{1}{C 2} \cdot \ln \left[\frac{V(t)-\frac{C 1}{C 2}}{V_{0}-\frac{C 1}{C 2}}\right]+t_{0}
\end{gathered}
$$




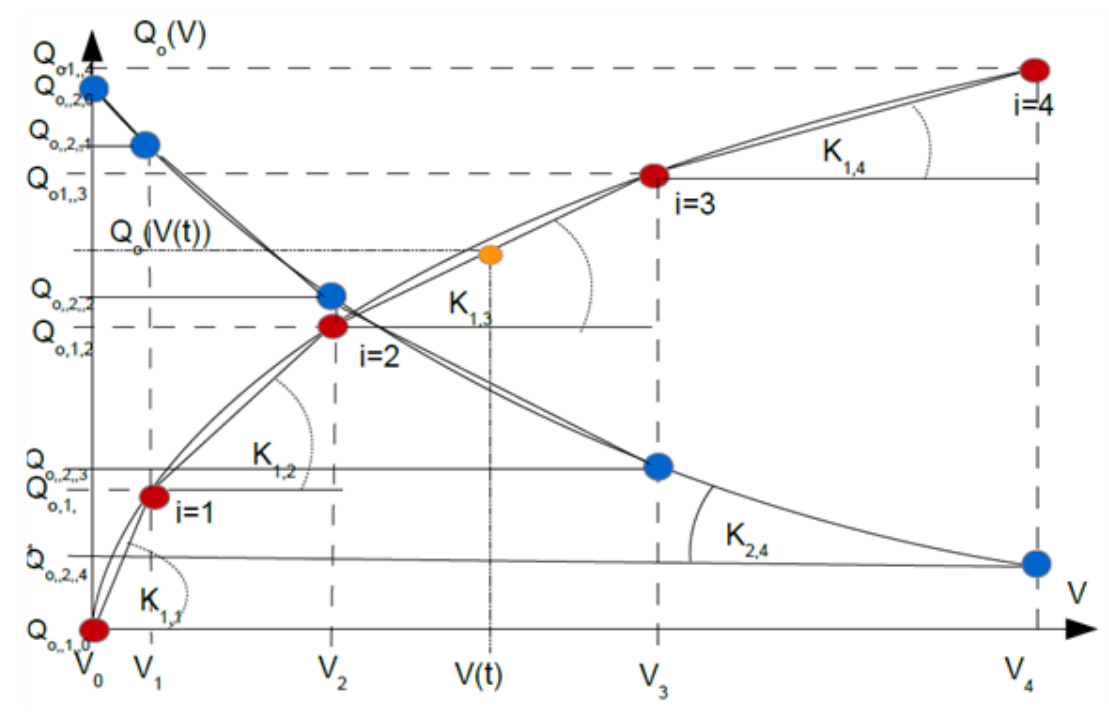

Fig. 8. Substitution of nonlinear functions by piecewise linear segments [22].

Outflows (releases) from AHDR: The outflows (release) from AHDR is the annual allocation of Egypt based on the agreement with Sudan $\left(55.5 \mathrm{~km}^{3}\right)$ in addition probably the releases for safety purpose if the level of water in AHDR being extremely high. The monthly outflows are fixed to meet exactly the predefined downstream water requirements unless the maximum or minimum capacity constrains are violated. In this simulation, the monthly releases from AHDR to Egypt, approximately the 1982 discharge program of AHD Authority, are used (Table 4) [23].

Table 4: Monthly releases from AHDR expressed in $\mathrm{km}^{3} / \mathrm{month}$ [23].

\begin{tabular}{|l|l|l|l|l|l|c|c|c|c|c|c|}
\hline Jan & Feb & Mar & Apr & May & Jun & Jul & Aug & Sep & Oct & Nov & Dec. \\
\hline 3.49 & 4.24 & 4.59 & 4.41 & 5.09 & 6.51 & 6.89 & 5.59 & 3.62 & 3.80 & 3.71 & 3.60 \\
\hline
\end{tabular}

Toshka spillway outflow: When the level of water is upper than 178 meters, the excess water is transferred to Toshka depression through the free spillway of Toshka. The discharge is calculated using a weir equation form [24]:

Where:

$$
Q=\beta *\left(H-H_{o t}\right) * g * 30.40 * 10^{-3}
$$

$\boldsymbol{\beta}$ is $19.0, \mathbf{g}$ is 1.6667.

$\mathbf{H}$ is the average water level, $\mathbf{H}_{\mathbf{o t}}$ is the crest level of the diversion (178 meters). 
Hydropower generation: The subsequent equation calculates the monthly probable hydropower generation from AHD:

$$
\begin{aligned}
& \mathrm{P}=9.81 * \mathrm{H} * \mathrm{Q} * \mathrm{C}_{\mathrm{e}} \\
& \mathrm{E}=\mathrm{P} * \mathrm{~K}
\end{aligned}
$$

Where:

$\boldsymbol{P}$ : The generated hydropower $(\mathrm{kW})$.

$\boldsymbol{E}$ : The generated energy (kWh).

$\boldsymbol{Q}$ : The discharges through the turbines $\left(\mathrm{m}^{3} / \mathrm{s}\right)$

$\boldsymbol{H}$ : The average water head on the turbines $(\mathrm{m}),=($ level of water upstream AHD - 110) [23].

$\boldsymbol{C}_{\boldsymbol{e}}$ : Total efficiency $(0.85)$.

$\boldsymbol{K}_{t}$ : Number of hours in the examined period (hours).

Evaporation losses: The average monthly losses due to evaporation from AHDR is computed using the subsequent equation:

$$
\boldsymbol{E}_{\boldsymbol{t}}=\left(\left(\mathrm{A}_{\mathrm{s}}+\mathrm{A}_{\mathrm{e}}\right) / 2\right) * \mathrm{C}_{\mathrm{t}} * 1000
$$

Where:
$A_{s}$ : Area of storage at starting of month $\mathrm{t}\left(\mathrm{km}^{2}\right)$.
$A_{e}$ : Area of storage at ending of month $\mathrm{t}\left(\mathrm{km}^{2}\right)$.
$C_{t}$ : The average daily evaporation of month $\mathrm{t}(=6.33 \mathrm{~mm})$ [25]

\subsection{Simulation Procedures}

The overall receding for simulation of AHDR involves:

- The calculations of inflow hydrograph are performed. These calculations are regarded to the historical monthly distribution of similar and close value inflow floods to form hydrograph for inflows the required amount and more realistic distribution.

- The model monitors both; the level of water upstream AHD and the outflows from the dam. The task is to ensure that the highest water level upstream AHD is not exceeding the highest limit during any time step and, also, to avoid increasing of the releases downstream AHD greater than the safe limits if possible.

- The simulation time step for all variables is one month.

\subsection{Simulation Constraints}

The model constraints include operation polices were decided by MWRI according to different restrictions such as [26]: 
- Peak releases should not exceed 250 million $\mathrm{m}^{3} / \mathrm{day}$ to avoid excessive erosion and banks overtopping.

- At least 60 million $\mathrm{m}^{3} / \mathrm{day}$ should be discharged to meet drinking, irrigation, navigation, and additional necessities.

- The reductions in withdrawals should being if the reservoir contents in the working (live) storage zone were so much less $60 \mathrm{~km}^{3}$ on July 31, the details of the sliding scale for reductions are presented in Table 5.

Table 5: Sliding scale for reduction [19].

\begin{tabular}{|c|c|}
\hline Live Storage Contents $(\mathbf{S})\left(\mathbf{k m}^{\mathbf{3}}\right)$ on July 31 & Reduction percentage \\
\hline $\mathrm{S} \geq 60$ & full share \\
\hline $55 \leq \mathrm{S}<60$ & $5 \%$ decrease \\
\hline $50 \leq \mathrm{S}<55$ & $10 \%$ decrease \\
\hline $\mathrm{S}<50$ & $15 \%$ decrease \\
\hline
\end{tabular}

- On August $1^{\text {st }}$, the level of water upstream AHD should be held at $175.00 \mathrm{~m}$ to meet peak and low inflows necessities.

\subsection{Model calibration}

Calibration of the model was done by using the monthly levels upstream AHD for thirty years (1964-1994). The duration from 1964 to 1985 was used for the calibration purpose. On the other besides, the verification was achieved according to the duration from 1985 to 1994, as indicated in Figure 9. The accuracy of the tooled model was verified using the Mean Percentage Relative Error (MPRE) (\%). It is a measure of the difference between simulated and measured values.

The MPRE is defined as follows:

$$
M P R E=\frac{\sum\left[\left(\frac{\text { Numerical.result }- \text { Field.measurement }}{\text { Field.measurement }}\right) x 100\right]}{\text { Number.of.result }}
$$

Regarding to Figure 9, the model indicated confident results and provided similar results to actual data with a MPRE of $0.45 \%$ and $0.40 \%$ for the calibration and verification processes, respectively. 


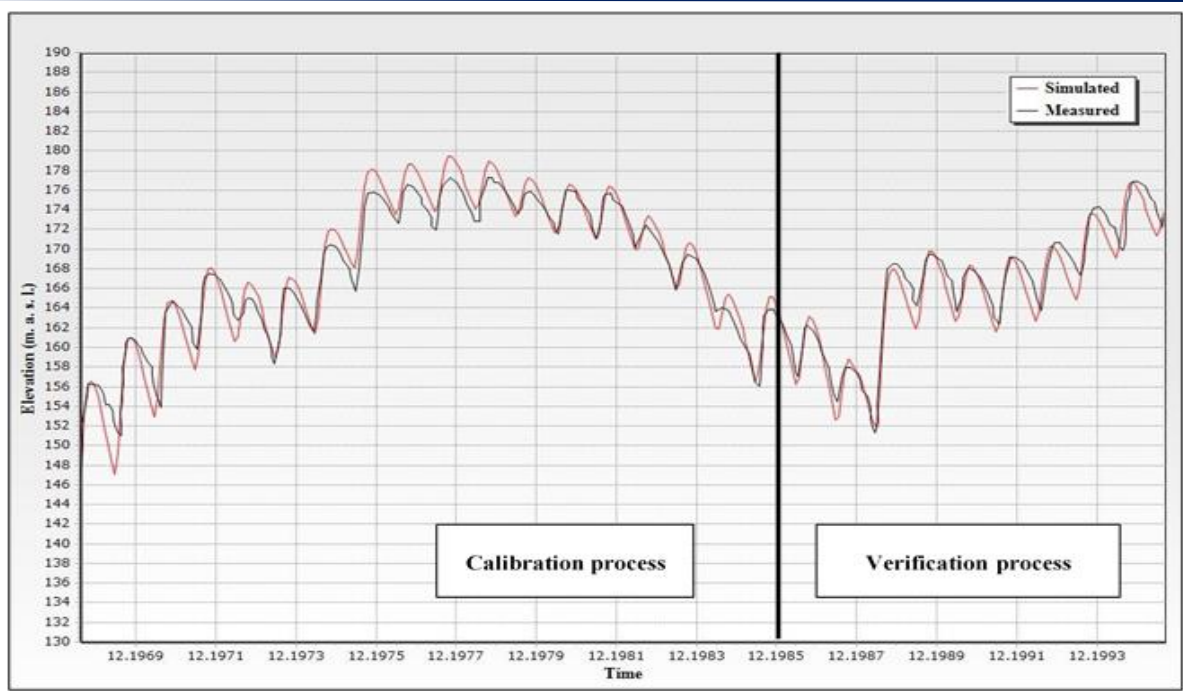

Fig. 9. Calibration and verification of the model.

\section{An assessment of the sedimentation influence on AHD operation}

Simulations were carried out to evaluate the sedimentation influence on AHD operation of the AHD during various inflow scenarios. Proportional investigation of AHD operation results for the two cases (with \& without) taking the sedimentation influence in the consideration has been conducted. In the following discussion, the assessment results are summarized relative to the following criteria: Toshka spillway outflows, water level, dam safety, water supply releases, evaporation losses and Hydropower generation.

\subsection{Influence of the sedimentation on the discharges (outflows) to Toshka spillway}

Figure 10 summarizes the statistical comparison of Toshka spillway outflows during 5 inflow scenarios for the two cases (with \& without) taking the sedimentation influence. Several conclusions can be derived from the outcomes showed in Figure 10. Under the baseline inflow scenario and without taking the sedimentation influence, the annual range of Toshka spillway outflows varied between $0.59-18.22 \mathrm{~km}^{3}$ with an average of about $4.62 \mathrm{~km}^{3}$ and occur in approximately $41.38 \%$ of results (see Fig. 11). With taking the sedimentation influence, the range of projected releases to the spillway grows to $0.91-18.22 \mathrm{~km}^{3}$ with an average of about $5.98 \mathrm{~km}^{3}$ and occur in approximately $41.38 \%$ of results. In addition, the outcomes demonstrate that the outflows discharged to Toshka spillway are influenced by increasing the annual inflow and raising water level upstream AHD. For example, the average range of Toshka spillway outflows in the 
maximum inflow scenario (20\% increase) increased significantly from $0.28-$ $22.87 \mathrm{~km}^{3}$ with an average of about $7.47 \mathrm{~km}^{3}$ and occur in approximately $75.86 \%$ of results for the case of (without) taking the sedimentation influence, to $0.01-$ $25.98 \mathrm{~km}^{3}$ with an average of about $8.19 \mathrm{~km}^{3}$ and occur approximately in $82.76 \%$ of results in case of (with) taking the sedimentation influence.

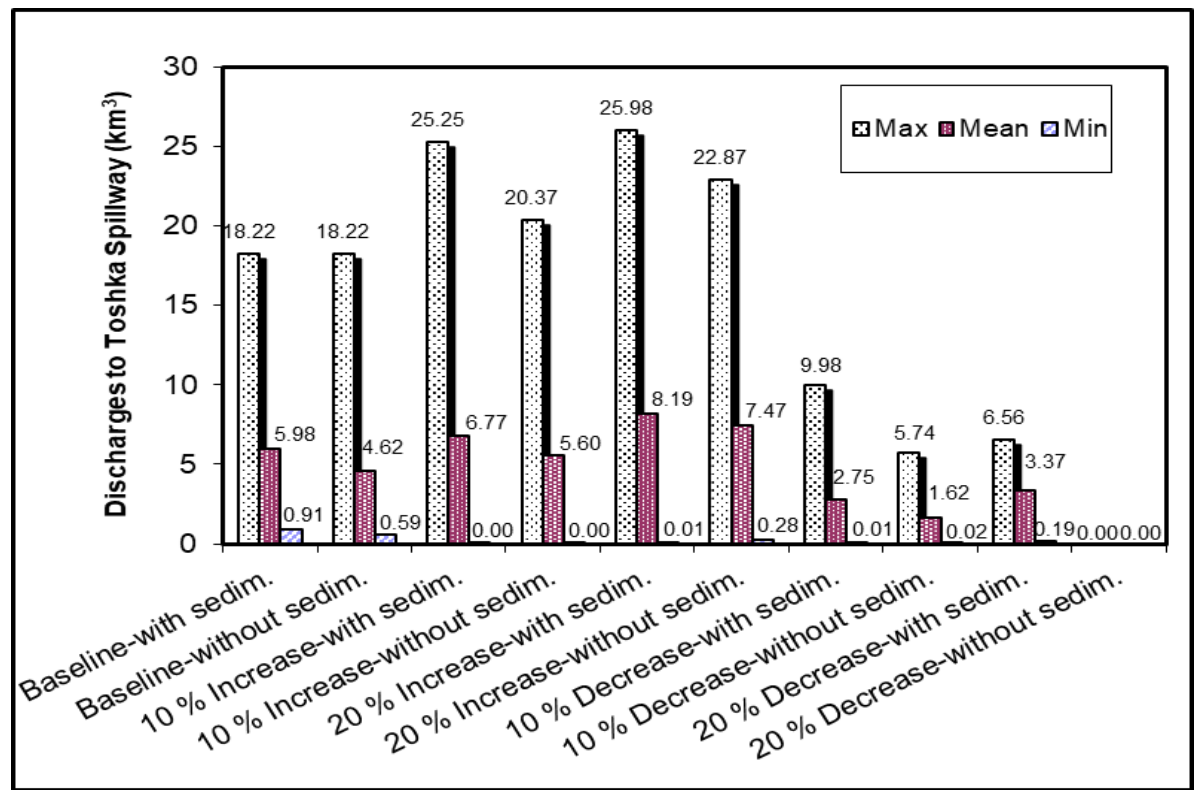

Fig. 10. Statistical comparison of Toshka spillway outflows for the two cases (with \& without) taking the sedimentation influence.

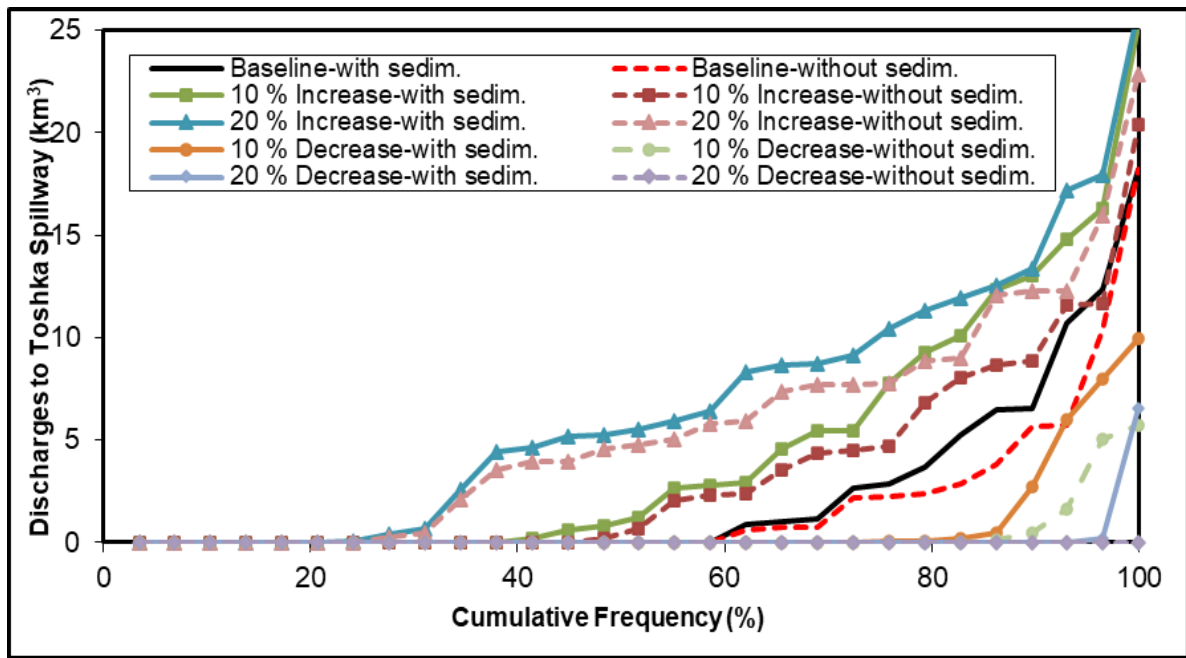

Fig. 11. Comparison of cumulative frequency curves of Toshka spillway outflows for the two cases (with \& without) taking the sedimentation influence. 


\subsection{Influence of the sedimentation on the levels and dam safety}

The main objective of the dams' design is to maximize the safety of dam. The safety of dam rest on mostly on the levels of water, that is affected by inflows. Improving dam safety is evaluated by considering the cumulative frequency of levels of water in a reservoir resulting from the long-term simulation. Figures 12 and 13 show analysis and comparison for the levels upstream AHD during baseline and four projected inflow scenarios for the two cases (with \& without) taking the sedimentation influence. From these figures, it can be determined that the levels upstream AHD are impacted by the sedimentation, this effect is more clearly appeared during low inflow scenarios .

For instance, the average range of levels upstream AHD in the maximum inflow scenario (20\% increase) varied between $170.28-183.40 \mathrm{~m}$ amsl with an average of about $177.44 \mathrm{~m}$ amsl and approximately $48.87 \%$ of results were less than this mean. With taking the sedimentation influence, the range of projected levels upstream AHD increases to $170.41-183.76 \mathrm{~m}$ amsl with an average of about $177.62 \mathrm{~m}$ amsl and approximately $49.72 \%$ of years were less than this mean. But during scenario of $20 \%$ decrease which presents the minimum inflow scenario, it may be found that the average range of levels upstream AHD (without) taking the sedimentation effect varied between $129.38-177.80 \mathrm{~m}$ amsl with an average of about $162.78 \mathrm{~m}$ amsl and approximately $40.39 \%$ of results were less than this mean. With taking effect of the sedimentation, the range of projected levels upstream AHD growths to $129.60-180.27 \mathrm{~m}$ amsl with an average of about $163.46 \mathrm{~m}$ amsl and approximately $40.68 \%$ of results were less than this average. Also, it may be drawn from these results that the probability of reaching water levels that threaten AHD safety with sediments case is higher than without them. This demonstrates the importance of taking the sedimentation influence when operating the AHDR. 


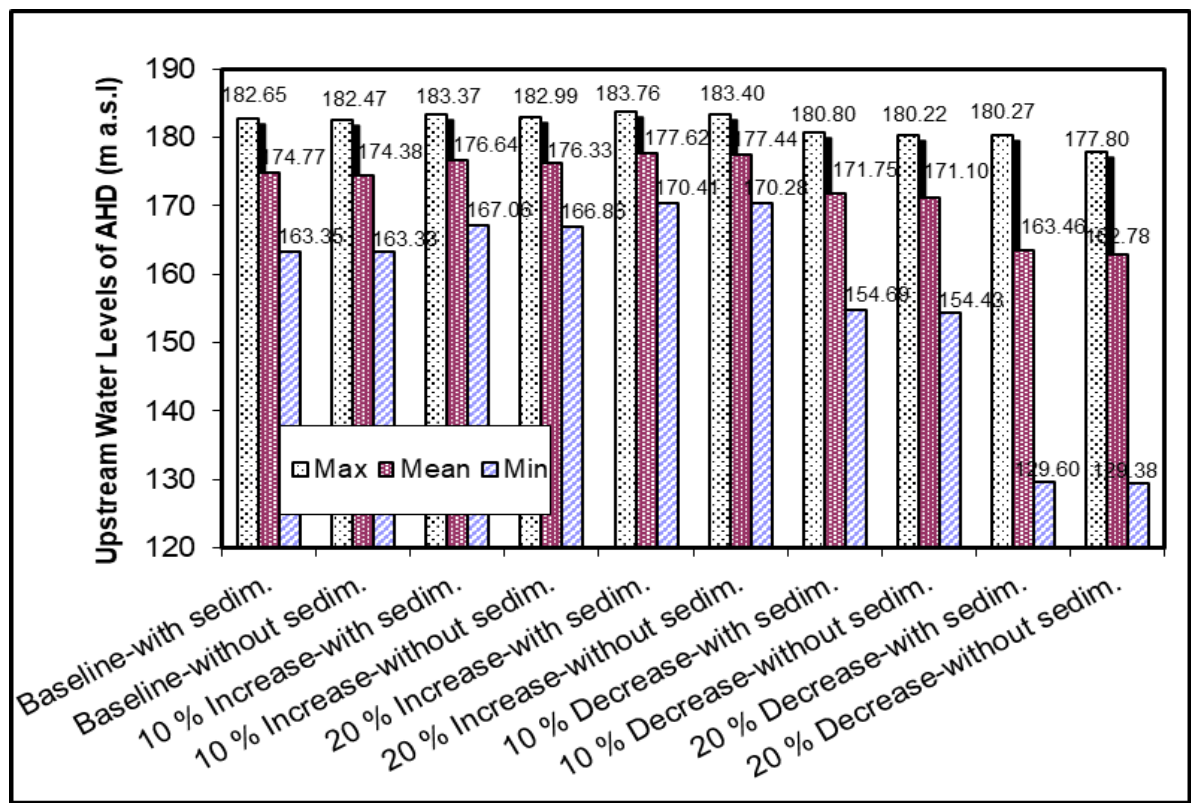

Fig. 12. Statistical comparison of levels upstream AHD for the two cases (with $\&$ without) taking the sedimentation influence.

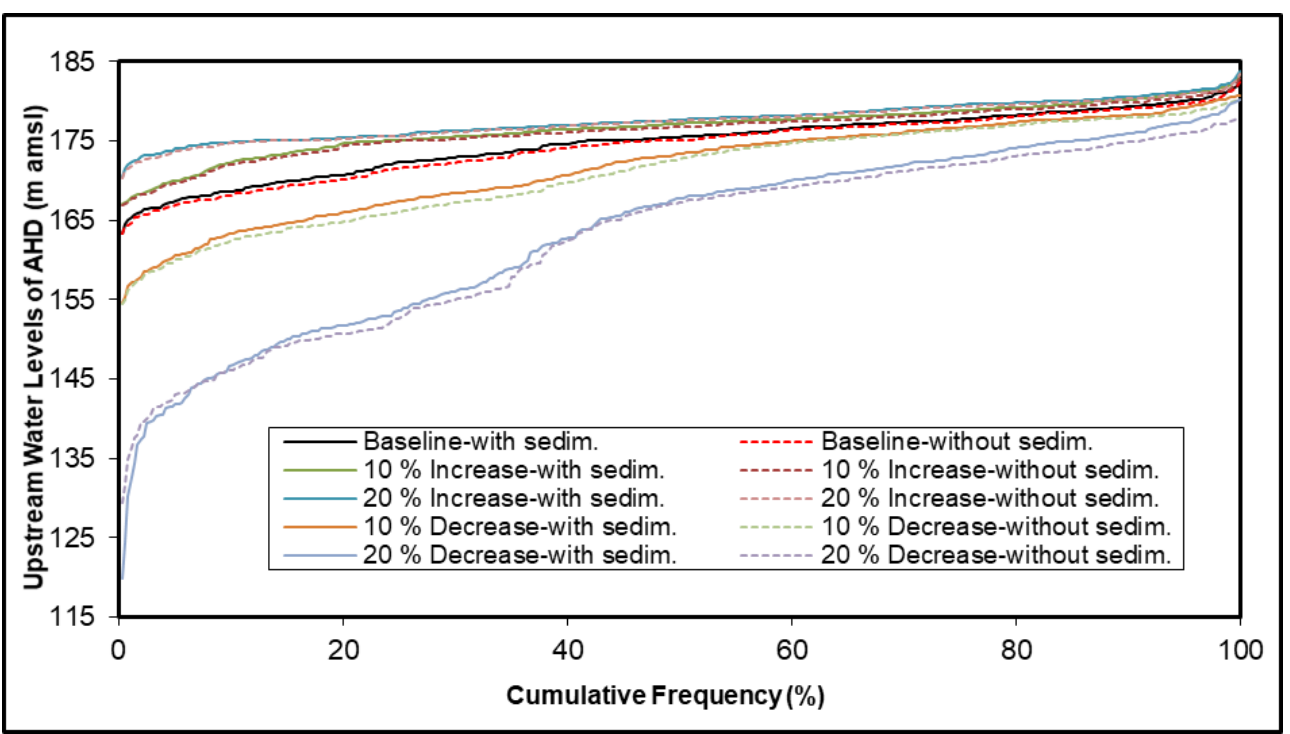

Fig. 13. Comparison of cumulative frequency curves of levels upstream AHD for the two cases (with \& without) taking the sedimentation influence.

\subsection{Influence of the sedimentation on the withdraw (releases) from AHDR}

Figure 14 presents comparison of the annual withdraw (releases) from AHDR for the two cases (with \& without) taking the sedimentation influence. From this Figure it can be ended that according to baseline inflow scenario, the mean annual 
Amir M. Mobasher, Influence of the Reservoir Sedimentation on the Dam Operation ......

suction from AHDR was $56.53 \mathrm{~km}^{3}$ without taking the sedimentation influence, this value increases to reach to $56.89 \mathrm{~km}^{3}$ with taking the sedimentation influence.

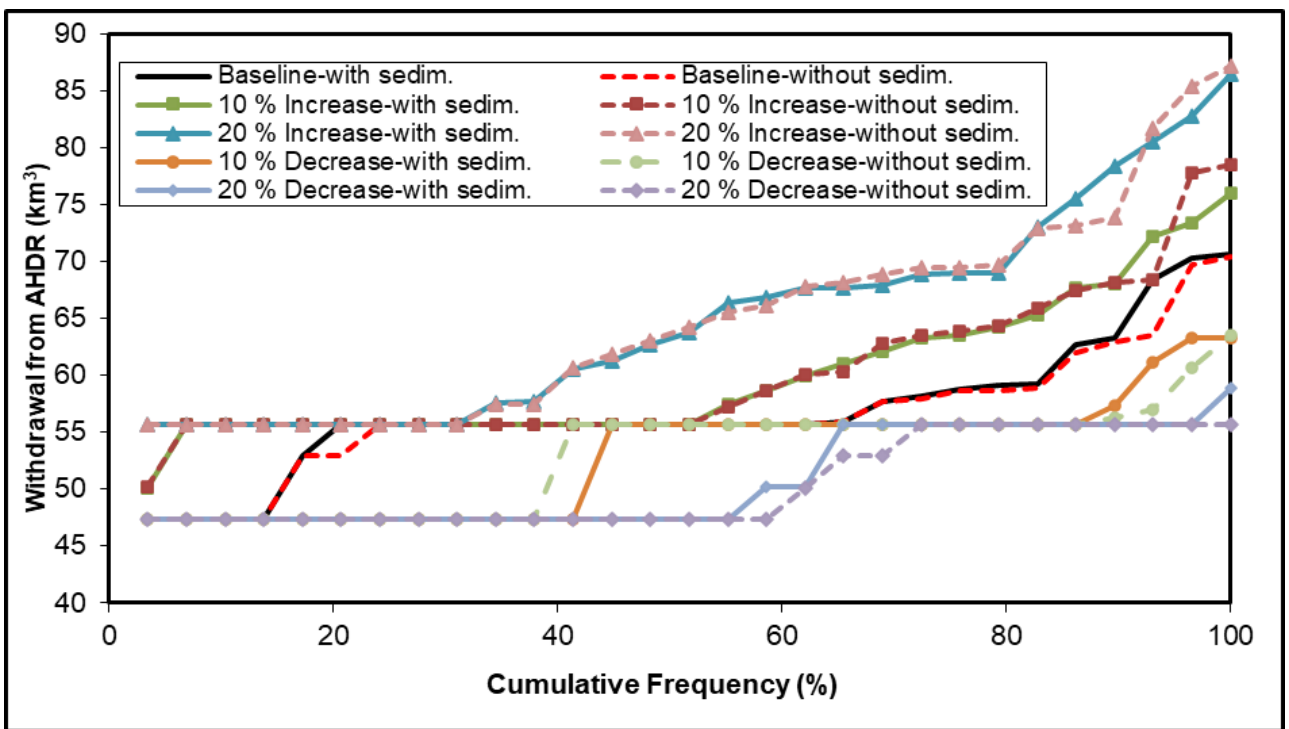

Fig. 14. Comparison of cumulative frequency curves of the annual withdrawal from the AHDR for the two cases (with \& without) taking effect of the sedimentation.

There are another few aspects of the cumulative frequency distributions that are also notable, under baseline inflow scenario, Egypt drops short of its objective demand in close to $17.24 \%$ and $20.69 \%$ of results years for the two cases (with \& without) taking the sedimentation influence. This percentage significantly increases during scenario of $20 \%$ decrease which presents the minimum inflow scenario to $62.07 \%$ and $68.97 \%$ of results for the two cases (with \& without) taking the sedimentation influence, respectively.

Also, Figure 14 shows how poorly effect the sedimentation on the results during high inflow scenarios. The reason for this is the storage capability loss due to sedimentation occurred mostly in the active (live) and the inactive (dead) storage zones and slightly in the flood control zone.

\subsection{Influence of the sedimentation on the losses due to evaporation}

The quantity of annual losses due to evaporation consists mainly of the storage area, which is impacted by the levels of water. And since that the sediments amount has affected the storage area, therefore it is expected that the value of the quantities of the losses due to evaporation with sediments case is lower than without them. Figure 15 illustrates the cumulative frequency of annual evaporation losses. According to the case of (with) taking the sedimentation influence case, the minimum scenario of the annual losses due to evaporation occur in inflow scenario 
(20\% Decrease) with an average range varies from $1.92-12.28 \mathrm{~km}^{3}$ with an average of about $7.49 \mathrm{~km}^{3}$. This numbers and range are compared to an average range varies from $2.76-12.58 \mathrm{~km}^{3}$ with a mean of about $7.96 \mathrm{~km}^{3}$ for (without) taking the sedimentation influence case. For the case of (with) taking the sedimentation influence $27.59 \%$ of results had losses due to evaporation higher than $10 \mathrm{~km}^{3}$ during minimum scenario, while this percentage reached to $31.03 \%$ of results for (without) taking the sedimentation influence case in the same inflow scenario.

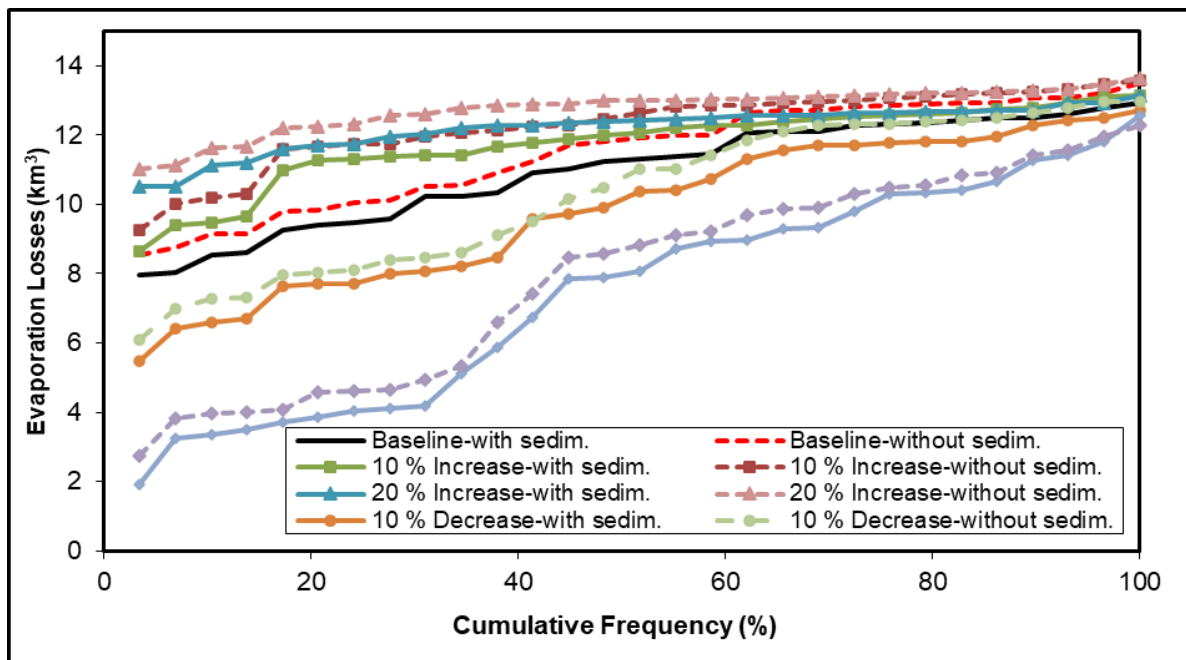

Fig. 15. Comparison of cumulative frequency curves of the annual losses due to evaporation from AHDR for the two cases (with \& without) taking the sedimentation influence.

The maximum scenario of the annual losses due to evaporation occur in inflow scenario (20\% Increase) with an average range varies from $10.52-13.15 \mathrm{~km}^{3}$ with an average of about $12.21 \mathrm{~km}^{3}$ for the case of (with) taking effect of the sedimentation. This numbers and range are compared to an average range varies from $11.01-13.63 \mathrm{~km}^{3}$ with a mean of about $12.75 \mathrm{~km}^{3}$ for (without) taking the sedimentation influence case. Almost all years during maximum scenario for both cases (with \& without) taking the sedimentation influence had losses due to evaporation higher than $10 \mathrm{~km}^{3}$.

\subsection{Influence of the sedimentation on the hydropower generation from AHD}

The variation in the hydropower generation with and without taking the sedimentation effect is compactly related to the variation in levels of water and the releases downstream AHD. This fact is confirmed by Figure 16, which displays Statistical comparison of hydropower generation by AHD for the two cases (with 
$\&$ without) taking the sedimentation influence. Figure 16 indicates that, during the minimum inflow scenario (20\% Decrease), annual hydropower generation by AHD without taking the sedimentation influence varied between 2863 - 8001 Giga watt hour (GWh) with an average of about $5801 \mathrm{GWh}$. with taking the sedimentation influence, these values change to $2469-8705 \mathrm{GWh}$ and $5921 \mathrm{GWh}$ for the range and the average, respectively. Also, as shown in Figure 16, during maximum inflow scenario ( $20 \%$ increase), the change in the annual hydropower generation from AHD due to effect of the sedimentation is slightly changed, because the change in the reservoir levels and the releases downstream AHD during high inflow scenarios is approximately negligible.

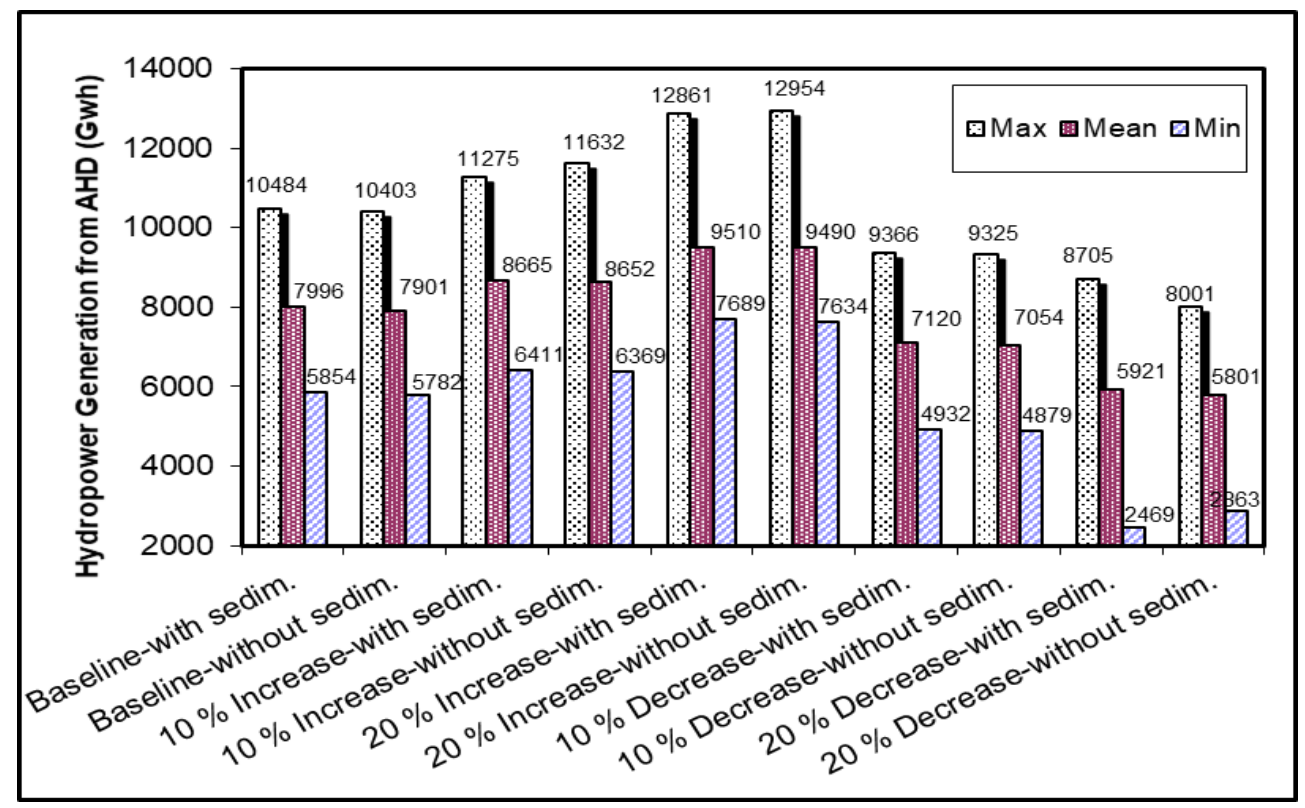

Fig. 16. Statistical comparison of hydropower generation from AHD for the two cases (with \& without) taking the sedimentation influence.

\section{Conclusions}

This study investigated the sedimentation influence on AHD operation. The following conclusions of could be drawn:

- The study developed and calibrated a new simulation model for AHDR. The model could evaluate the functioning of AHDR functioning below different hydrologic conditions and operation policies and any kind of structural changes.

- The outcomes of the study indicated that Toshka spillway outflows, dam safety, levels of water upstream AHD, the releases from the reservoir, the 
quantities of losses due to evaporation and the quantity of hydropower generated from the dam were affected due to presence of these deposits in AHDR. This effect varied in accordance with the Nile inflows scenarios into the reservoir.

\section{Recommendations}

The study highlights the following recommendations:

1. Effect of the reservoir sedimentation should be considered to implement or develop of simulation models for the AHDR.

2. It is wished that the outcomes of these assessments will lead to more informed the AHDR strategies for future enhancement, adaptive management, and risk evaluation.

\section{REFERENCES}

[1] Walling, D. \& Fang, D. (2003), "Recent trends in the suspended sediment loads of the world's rivers," Global Planet. change, 39:111-126.

[2] Sumi, T. \& Hirose, T. (2009), "Accumulation of sediment in reservoirs, Water storage," transport and distribution, UNESCO-IHE and EOLSS Publishers Co. Ltd., Paris, France, 224-252.

[3] Carvalho, N. O., (1998), "Sedimentation and Protection of Reservoirs," VI National Symposium of Erosion Control, ABGE, Brazil (in Portuguese .

[4] Kande S., (2009), "Reservoir Sedimentation and its Hydrological Impacts: A case Study of Khodiar Reservoir", Unpublished ME Dissertation, LD College of Engineering, Ahmedabad, Gujarat, India.

[5] Obialor, C. A., Okeke, O. C., Onunkwo, A. A., Fagorite, V. I., and Ehujuo, N. N., (October 2019), "Reservoir Sedimentation: Causes, Effects And Mitigation", International Journal of Advanced Academic Research | Sciences, Technology and Engineering | ISSN: 2488-9849 Vol. 5, Issue 10.

[6] EL-Sersawy H. and Farid MS. (2005), "Overview of Sediment Transport Evaluation and Monitoring in the Nile Basin. In". Ninth Inter. Water Tech. Conf. (NIWTC), Sharm El-Sheikh, Egypt. [As reported in Amary W. Study the Sedimentation inside High Aswan Dam Reservoir, M.Sc. Thesis, Faculty of Engineering, Cairo University; 2008].

[7] Tidwell, A. C., (December 2006), "Assessing The Impacts Of Climate Change On River Basin Management: A New Method With Application To The Nile River," A Dissertation in Partial Fulfillment of the Requirements for the Degree Doctor of Philosophy in the School of Civil and Environmental Engineering, Georgia Institute of Technology.

[8] (MWRI, (2005), "Water for The Future, National Water Resources Plan 2017 (NWRP)," Cairo, Egypt. 
Amir M. Mobasher, Influence of the Reservoir Sedimentation on the Dam Operation ......

[9] EL-Sersawy, H., (2005), "Sediment Deposition Mapping in Aswan High Dam Reservoir Using Geographic Information System (GIS)," Ninth Inter. Water Tech. Conf., IWTC9, Sharm El-Sheikh, Egypt.

[10] Shalash, S., (1982), "Effects of Sedimentation on The Storage Capacity of The High Aswan Dam Reservoir," Hydrobiologia 92, 623-639.

[11] Ismail, S. S., and Aziz, M., (2005), "Toshka Spillway Barrages Stability Analysis," Ninth International Water Technology Conference, IWTC9, Sharm El-Sheikh, Egypt.

[12] EL-Sersawy H. and Farid MS. (2005), "Overview of Sediment Transport Evaluation and Monitoring in the Nile Basin. In". Ninth Inter. Water Tech. Conf. (NIWTC), Sharm El-Sheikh, Egypt. [As reported in Amary W. Study the Sedimentation inside High Aswan Dam Reservoir, M.Sc. Thesis, Faculty of Engineering, Cairo University; 2008].

[13] El-Moattassem M., Abdel-Aziz T. M., and EL-Sersawy, H., (2005), "Modeling of Sedimentation Process in Aswan High Dam Reservoir". Ninth International Water Technology Conference, Sharm El Sheikh, Egypt.

[14] Hassan W. E., (2008), "Study of Sedimentation Inside the Lake of The High Dam," Master Thesis, University of Al-Azhar, Cairo, Egypt.

[15] Elsaeed G. H., Aziz M. S., and Ziada W.M, (2016), "Sedimentation Analysis and Prediction for Aswan High Dam Reservoir," Journal of Scientific and Engineering Research, 2016, 3(4):302-312, ISSN: 2394-2630.

[16] Moussa A. M., (2013), "Predicting the deposition in the Aswan High Dam Reservoir using a 2-D model," Ain Shams Engineering Journal, 4, 143-153.

[17] Fahmy H., (2001), "Modification and Re-calibration of the Simulation Model of Lake Nasser," in International Water Resources Assocation, volume 26, Number 1, pp. 129-135.

[18] El-Shazli A. and Hoermann G., (2016), "Development of storage capacity and morphology of the Aswan High Dam Reservoir," Hydrological Sciences Journal, ISSN: 0262-6667 (Print) 2150-3435.

[19] Shafik N., (2016), "Updating the surface area and volume equations of Lake Nasser using Multibeam System, in: Nineteenth International Water Technology Conference IWTC 19, Sharm El Sheikh, Egypt.

[20] Yao, H., and Georgakakos, A. P., (June 2003), "Nile Decision Support Tool River Simulation And Management," Georgia Water Resources Institute (GWRI), Atlanta.

[21] NRI 2012, Nile Research Institute Database, NRI, NWRC, Egypt.

[22] Ostrowski, M., (July 2014), "A Generic Mathematical Formulation of a Piecewise Linear Approximation of Nonlinear Hydrological Storage Processes," Report in Darmstadt University of technology, Darmstadt, Germany.

[23] Sutcliffe, J. V., and Parks, Y. P., (1999), "The Hydrology of The Nile," The Inter. Assoc. of Hydrological Sciences, IAHS Special Publication no. 5, ISBN 1-90150275-9, UK.

[24] Georgakakos, A. P., Yao, H., and Miller, F., (May 1997), "A Decision Support System For The High Aswan Dam," Waterpower.

[25] Hassan, R., Hekal, N., and Mansor, N., (2007), "Evaporation Reduction from Lake Naser Using New Environmentally Safe Techniques," Eleventh International Water Technology Conference, IWTC11 Sharm El-Sheikh, Egypt. 
[26] Ministry of water resources and irrigation, (2013), "Proposed Climate Change Adaptation Strategy for the Ministry of Water Resources \& Irrigation in Egypt," Cairo, Egypt.

\section{تأثير تزسيب الخزان على تثغيل السد - دراسة حالة السد العالي بأسوان في مصر الفئ}

ملخص البحث

تُعتبر الخزانات مصدرًا مهمًا لإمدادات المياه، وتوفر الطاقة المائية، وتحد من آثار الجفاف

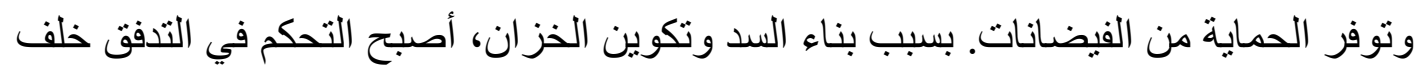

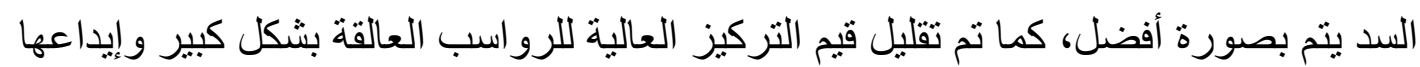

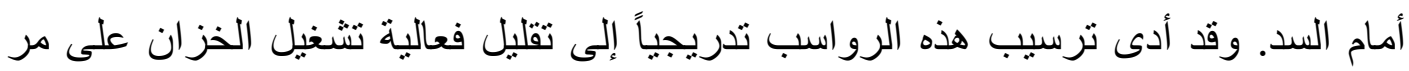

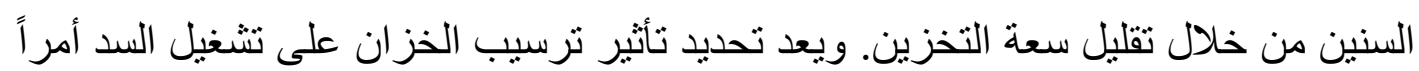

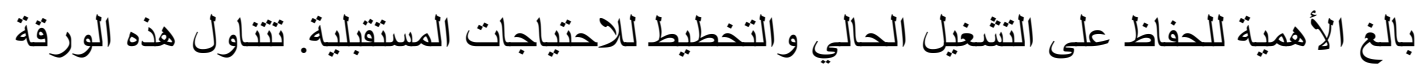
البحثية مر اجعة وتحليل تأثثير ترسيب الخزان على تشغيل السد العالي بأسوان في مصر . حيث

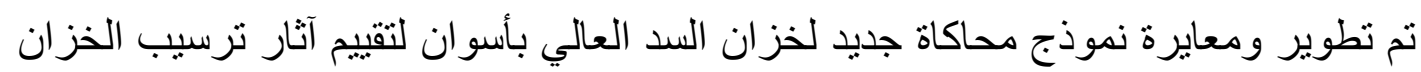

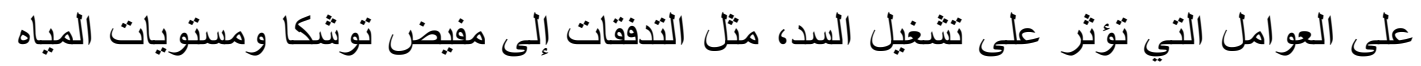

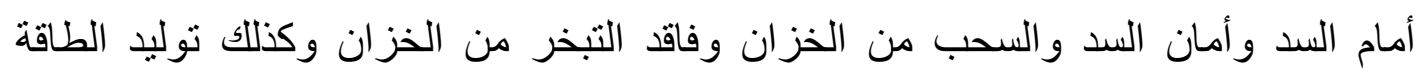
الكهرومائية من السد. وقد أظهرت نتائج الدراسة أن العوامل التي تؤثر على تشنغيل السد وند

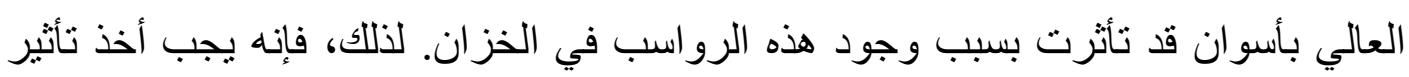

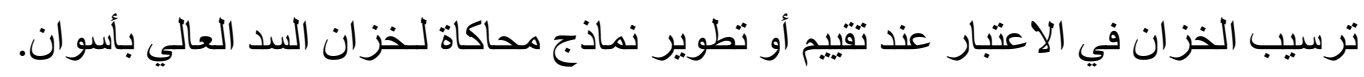

